\title{
Monsters Evolve: A Biocultural Approach to Horror Stories
}

\author{
Mathias Clasen \\ Aarhus University
}

\begin{abstract}
Horror fiction is a thriving industry. Many consumers pay hard-earned money to be scared witless by films, books, and computer games. The well-told horror story can affect even the most obstinate skeptic. How and why does horror fiction work? Why are people so fascinated with monsters? Why do horror stories generally travel well across cultural borders, if all they do is encode salient culturally contingent anxieties, as some horror scholars have claimed? I argue that an evolutionary perspective is useful in explaining the appeal of horror, but also that this perspective cannot stand alone. An exhaustive, vertically integrated theory of horror fiction incorporates the cultural dimension. I make the case for a biocultural approach, one that recognizes evolutionary underpinnings and cultural variation.
\end{abstract}

Keywords: horror fiction, monsters, fear, biocultural analysis, evolutionary psychology

Our fear of monsters in the night probably has its origins far back in the evolution of our primate ancestors, whose tribes were pruned by horrors whose shadows continue to elicit our monkey screams in dark theaters. (Shepard, 1996, p. 29)

The popularity of horror fiction is puzzling. Why would anyone willingly expose himself or herself to such aversive, outlandish nonsense; what is the appeal of supernatural monsters and moaning ghosts? I argue that a biocultural approach, one that integrates research into evolved psychology with attention to sociohistorical circumstance, is uniquely equipped to answer these questions. By taking into account evolved cognitive architecture, a biocultural approach offsets the tendency toward cultural determinism inherent in the widespread socioconstructivist approach to horror (e.g., Kendrick, 1992; Skal, 2001). Human cognition has been fine-tuned by natural selection to deal with dangers in the environment, and horror fiction depends crucially on this mental machinery.

Horror fiction is a multimillion-dollar industry. For the past decade and a half, horror films have enjoyed a market share of about $5 \%$ (not counting the closely related, sometimes overlapping genres of thriller and suspense films; The Numbers-TopGrossing Genres, 2011). The horror film Paranormal Activity (2007), produced for a measly $\$ 15,000$, has grossed close to $\$ 200,000,000$ worldwide (Paranormal Activity, 2011), despite its thin storyline and dubious premise of an angry demon from Hell. In literature, Stephen King and his fellow horror mongers continue to thrill audiences around the planet with stories of the grotesque

I am immensely indebted to Joe Carroll for his eagle-eyed editorial assistance and unstinting support. I also would like to warmly thank Daniel Sznycer for giving feedback on a draft of this article; my colleagues at Interdisciplinary Evolutionary Studies, Aarhus University, for valuable discussions and support; and Leda Cosmides, John Tooby, and the other good people at the Center for Evolutionary Psychology, University of California, Santa Barbara, for providing a stimulating writing environment.

Correspondence concerning this article should be addressed to Mathias Clasen, Department of English, Aarhus University, DK-8000 Aarhus C, Denmark. E-mail: engmc@hum.au.dk and macabre. Video games manifestly designed to maximally spook players, such as Silent Hill, are a thriving enterprise.

The fact of the matter is that creepy stories of ghosts, monsters, crazed killers, and otherworldly hauntings continue to draw flocks of thrill-seekers to the comfortable half-darkness of cinemas and the shelves labeled "horror" in bookstores and libraries worldwide. The well-told horror story can send a shudder down the spine of even the most obstinate rationalist. Why is it that educated, enlightened persons are susceptible to being frightened by fictional tales about supernatural monsters, and why are many people attracted to such stories? Why does commercial horror fiction travel so well across cultural borders? Apparently, even the glare of scientific progress and general enlightenment are insufficient to kill off the supernatural menaces that stalk us in the stories we consume.

Something about vampires, zombies, ghosts, werewolves, and chainsaw-wielding maniacs makes them uniquely interesting to many people. But the ubiquity of such monsters in fiction certainly cannot be a reflection of reality-let alone the reality of 21 st century citizens in industrial countries. The likelihood of being assaulted by a homicidal maniac in a hockey mask is only marginally greater than the likelihood of being assaulted by a thirsty vampire or a hungry zombie. I argue that horror stories do not reflect empirical reality but rather the psychology of our species. The sustained generation and consumption of horror fiction over space and time suggest that a species-typical cognitive architecture for dealing with danger is brought into play by such stories. In this article, I provide a brief sketch of cognitive architecture designed for danger management and analyze the correspondence between this mental machinery and the structure of horror fiction and horror monsters.

\section{Natural-Born Scaredy-Pants}

Before we turn to the current profusion of monsters in popular entertainment, we need to take a look at our past. The Homo line diverged from that of our closest relatives, the chimpanzees and bonobos, about 5 to 7 million years ago, and a long process of natural selection further whittled away at our species and gave rise 
to anatomically modern humans some 200,000 years ago (Wade, 2007). It means that we all have human nature in common, that is, a set of genetically transmitted traits and dispositions common to all members of the species Homo sapiens sapiens. All organisms evolve in an adaptive relationship with their environments. Organisms that are better suited to their physical, ecological, or social environments leave more offspring, increasing their genetic representation in future generations. All living humans are thus descended from a very long line of well-adapted organisms, none of whom failed at the exacting tasks of surviving and reproducing. Coping with dangers is a major challenge in the evolutionary process. Today, as in our prehistorical evolutionary past, human beings are born into the world with a suite of adaptations designed for managing a wide array of dangers.

Imagine this. You are alone, at night, walking in the woods. From somewhere, suddenly, come a sound, a rustling, and something that sounds like growling. These auditory cues, perhaps implying lethal danger from a predator, generate in you a precautionary neurophysiological reaction. Attention is sharply focused on the potential threat, all thoughts of the upcoming Sex and the City marathon or soccer match forgotten. Your pulse climbs, you start sweating, your mouth dries out, energy is directed to the big muscles and away from the digestive system: These various responses are jointly mobilized by the emotion of fear (Tooby \& Cosmides, 2000). Your body prepares for confrontation or flight, pending further evidence. It could be a false alarm, but given that reacting to a false alarm is vastly less catastrophic than failing to react to a lethal threat, responding with a heightened state of emergency is a safe bargain and hence the baseline response (Marks \& Nesse, 1994).

Now imagine this. You are alone, at night, watching a Japanese horror movie on cable. From somewhere, suddenly, comes a little pale girl with long black hair. Similar physiological changes take place in your body, even though there is no physical danger. But we scare easily - jumping at shadows is simply the safer bargainand even virtual danger scenarios such as horror fiction capitalize on this tendency.

\section{Psychological Adaptations to Danger}

Like all other animals, humans are equipped with evolved machinery that enables them to deal with possible dangers to their survival, and emotions are crucial parts of the machinery. In humans, fear is mediated by highly conserved, ancient circuits in the brain. In fact, humans and rats respond to sudden danger in much the same way (LeDoux, 1996, pp. 130-131). Emotions are functional systems that guide behavior, deeply embedded in mammalian brains (and perhaps other classes of animals as well). Fear and anxiety are adaptations to dangerous environments. They help us stay clear of things that could be harmful to us.

Life in ancestral environments was dangerous. We know from the archeological record that humans and our hominid ancestors were frequently prey to other animals and also to fellow humans. So, for example, we find skulls of hominins with puncture marks that match perfectly the teeth of large feline predators (Hart \& Sussman, 2008). The vast majority of our species' evolutionary history was spent living in small bands of hunter-gatherer societies, and we know from anthropological studies of modern-day hunter-gatherer societies that such existence is dangerous. Among
Aché foragers in Paraguay, 6\% of all deaths are the result of poisonous snakebites, making this the single most common lethal accident. Among adult males, snakebites account for $14 \%$ of all deaths, and jaguar attacks for another $8 \%$. Death by the hands of other humans is even higher than deaths due to animal predation: External warfare accounts for $36 \%$ of deaths among adult males. Violence generally is responsible for 55\% of all Aché deaths (Hill \& Furtado, 1996, pp. 162-163).

We would expect this kind of precarious existence to have left deep grooves in human nature. And indeed, experimental psychologists have provided a wealth of evidence for the kind of dedicated threat-detection and handling system that this selective regime would shape. Humans' attention is preferentially engaged by evolutionarily recurrent, fear-relevant stimuli. So, for example, test subjects are faster at detecting an image of a snake among a mass of flowers than they are at detecting a flower among a mass of snakes (Öhman, Flykt, \& Esteves, 2001), the hypothesis being that the danger from poisonous snakebites exerts a selection pressure for fast detection of serpents. Summing up previous research, Arne Öhman (2000) wrote that

responses of fear and anxiety originate in an alarm system shaped by evolution to protect creatures from impending danger. This system is biased to discover threat, and it results in a sympathetically dominated response as a support of potential flight or fight. (p. 587)

The fear response is controlled by the autonomic nervous system and so is largely impervious to higher order cognitive control, and the system is biased, that is, hyper-responsive and prone to erring on the side of caution. Thus, Öhman and Mineka (2001) posit a dedicated fear module that directs attention toward potential threats, causes appropriate emotional states, and produces behavioral outputs that are, on average and statistically speaking, adaptive (see also Boyer \& Bergstrom, 2011; Boyer \& Liénard, 2006; Eilam, Izhar, \& Mort, 2011; Liénard, 2011; Neuberg, Kenrick, \& Schaller, 2011; and Woody \& Szechtman, 2011). Humans, like other animals, are born with preprogrammed instructions for what kind of dangers might exist in the world, and experience (firsthand or vicarious) fills in the picture. Being born with an abstract predator template-for example, a template specifying large animals with sharp teeth and forward-facing eyes - and an instruction to pay attention to such predators gets the job done $(\mathrm{H}$. C. Barrett, 2005). Evolved danger-management systems require calibration, a useful design feature because different biotopes offer somewhat different threats. In one environment, it may be useful to be on the lookout for wolves; in another, crocodiles; in yet another, mountain lions.

This substrate of genetically prepared learning gives a "nonrandom distribution of fears" (Marks \& Nesse, 1994, p. 255). It is vastly easier to acquire fear of spiders or large animals than to acquire fear of saturated fats or cars, despite the fact that cardiovascular disease and automotive accidents are more likely to kill us by several orders of magnitude. This distribution is reflected in horror stories that feature fearsome monsters. Modern-day horror stories, by flinging us into virtual universes that brim with lurking dangers and aggressive predators, send us on a journey backward in time, to the dark days in human phylogeny when the setting sun signified grave danger and real monsters could very well be gathering just outside the fragile circle of light cast by the bonfire. 


\section{Horror Stories Trigger Evolved Danger-Management Systems}

All normally developed humans are equipped with cognitive machinery dedicated to threat detection and handling, machinery that has been assembled and fine-tuned incrementally by a long process of natural selection. We have evidence to suggest that horror fiction runs on the same machinery. For example, researchers studying emotion have found horror films very effective for ecologically valid emotion elicitation in laboratory experiments on fear. In particular, researchers have found clips from The Shining (1980) and Silence of the Lambs (1991) useful as fear-eliciting stimuli (Gross \& Levenson, 1995; Rottenberg, Ray, \& Gross, 2007). We can draw two conclusions from this research: Horror movies cause predictable, reliable emotional states across subjects (people do not interpret what they watch arbitrarily), and horror films engender actual emotions of fear and anxiety, not simulacra or perversions of these emotions.

Evidence is also forthcoming from an intriguing study of a woman with neurological impairment (Feinstein, Adolphs, Damasio, \& Tranel, 2011a). This patient, famous in neurological literature as SM, suffers from focal bilateral amygdala lesions. She is, in other words, fearless because of localized brain damage. In a recent experiment, a team of researchers subjected the woman to a variety of fear-inducing situations. They took her to a pet shop and exposed her to snakes and tarantulas, they dragged her on a tour of a haunted house, and they had her watch clips from a number of well-known horror films. In the pet store, SM was "spontaneously drawn to the snake terrariums." She asked repeatedly if she could touch or hold even large, dangerous snakes, and "also attempted to touch a tarantula, but had to be stopped because of the high risk of being bitten" (Feinstein et al., 2011a, pp. 34-35). When they visited Waverly Hills Sanatorium, a commercially run "haunted attraction" in Kentucky, SM showed no fear but reported "a high level of excitement and enthusiasm" (p. 35):

\begin{abstract}
The hidden monsters attempted to scare SM numerous times, but to no avail. She reacted to the monsters by smiling, laughing, or trying to talk to them. In contrast, their scare tactics typically elicited loud screams of fright from the other members of the group. More than showing a lack of fear, SM exhibited an unusual inclination to approach and touch the monsters. Ironically, SM scared one of the monsters when she poked it in the head because she was "curious" as to what it would feel like. (Feinstein et al., 2011a, p. 35)
\end{abstract}

The team exposed SM to clips of varying length from a number of horror films, including The Ring (2002), The Shining (1980), The Blair Witch Project (1999), Halloween (1978), Silence of the Lambs (1991), and Se7en (1995; Feinstein, Adolphs, Damasio, \& Tranel, 2011b, p. 9), all of which induced high levels of fear in healthy control subjects. As the authors note,

\begin{abstract}
SM exhibited no fear responses and reported experiencing little to no fear across the entire battery of fear-inducing films. Nonetheless, she found the fear films to be exciting and entertaining, and in one case, she inquired about the name of the movie so she could rent it from the video store later that day. (Feinstein et al., 2011a, p. 35)
\end{abstract}

It is striking that patient SM not only lacked fear but also displayed high interest in fearful situations and objects. As the research team argued, "fear-inducing stimuli are still capable of eliciting changes in attention and arousal through structures other than the amygdala" (Feinstein et al., 2011a, p. 37). Horror monsters are not only terrifying, they are captivating.

\section{Monsters Real and Imagined}

"What scares me is what scares you. We're all afraid of the same things. That's why horror is such a powerful genre," according to veteran horror filmmaker John Carpenter (as cited in McCarty \& McLaughlin, 2006). His observation has the ring of common sense, and is in fact borne out by research on the topic. People do tend to fear similar things simply because we are similarly constructed. A long process of evolution gave us minds that are on the lookout for certain kinds of dangers in the environment, dangers that are sometimes hopelessly atavistic. The same process gave us endlessly creative imaginations, and these two capacities together give rise to a multitude of fictional monsters.

The primary function of a fictional monster is to be salient. It can fulfill that function by being dangerous because humans are hard-wired to pay attention to dangerous agents, but the monster becomes even more interesting by being unnatural. Cognitive research on religion has produced evidence that counterintuitive agents, particularly minimally counterintuitive agents such as ghosts and bleeding statues, are more salient, easier to remember, and more likely to be faithfully transmitted than ordinary or completely bizarre agents (Boyer, 2001; J. L. Barrett, 2004; Norenzayan, Atran, Faulkner, \& Schaller, 2006; see Grodal, 2009, on the application of this finding to supernatural film).

Indeed, monsters appear in stories, myths, and artwork all over the world. As David Gilmore (2003) has documented through extensive anthropological research, "people everywhere and at all times have been haunted by ogres, cannibal giants, metamorphs, werewolves, vampires, and so on" (p. ix). Likewise, according to Stephen Asma (2009), the "monster archetype seems to appear in every culture's artwork" (p. 282). Psychology goes a long way toward explaining our fascination with made-up monsters and the underlying structure of monsters as unnatural dangerous agents. Horror monsters are usually supercharged predators with counterintuitive traits, well designed to capture and hold our attention. They are tailored to have a specific effect on the human mind, and the reason they succeed is that there are regularities in human cognitive architecture that make sense only in the light of our evolutionary history. Nonetheless, a cultural component is necessary to understand particular monsters and the historical development of the horror genre.

\section{Cultural Ecologies of Monsters}

Like all other imaginative constructs, monsters come into being in a complex relation between psychological machinery, environmental conditions, and cultural narratives: They grow in the soil of adapted minds and are fertilized by cultural ecology. Four examples will help clarify this principle: werewolves, zombies, vampires, and ghosts.

\section{The Werewolf}

Although the global entertainment industry has transmitted werewolves to the farthest corners of the planet, the creature began 
life as a tweaked version of a local predatory animal, the wolf. Asma (2009) noted, "in the imaginative construction of a frightening beast, a folk culture will frequently embellish the local predators rather than compose a completely novel monster" (p. 126). Thus, we find different shape-shifters in different ecologies: a were-tiger in India and other Asian regions, a were-bear in North America, a were-leopard in Africa, a were-boar in Greece and Turkey, a were-crocodile in Indonesia and Africa, and so on (Rose, 2000, pp. 389-390).

Different as these shape-shifters are on the surface, they are products of the same universal psychological processes producing output with local environmental and cultural inputs. Psychological adaptations that make humans interested in dangerous organisms, as well as mechanisms that make counterintuitive agents particularly salient to humans, coupled with a knowledge or impression of local predators and a memory bank of monster stories, work together to elaborate on the culturally transmitted idea of a shapeshifter and to make the were-animal a successful cultural figure. The various ethnic were-animals are variations on a basic theme, constrained by human cognition, and the very idea of a wereanimal is a spectacular embodiment of the commonsensical observation that human nature is fraught with conflicting forces, some of them dark and bestial. The werewolf is efficient both as a metaphor for the "beast within man" and as a literal, tweaked predator reminiscent of the kind of monsters that stalked our ancestors.

\section{The Zombie}

The zombie packs a double whammy in its dual assault as a physically dangerous agent that is riddled with pathogens. It wants to eat you, and it is extremely infectious. Furthermore, the zombie is a counterintuitive and thus salient idea: It is a reanimated human corpse and a "person" without a mind, or at least with severely impaired cognitive functioning (and thus the opposite of a ghost, a mind without a body). From about 1925, the representation of zombies in English-language books increased by more than $500 \%$, and by 2000 it had increased by 3,250\% (see Figure 1). The most important turning point was George A. Romero's film Night of the Living Dead (1968), a disturbing and commercially successful film that pushed the stumbling zombie into the spotlight of mass entertainment.

Why did the zombie become so popular so quickly and in this particular era? Some commentators have isolated cultural anxieties that zombies are somehow supposed to engage with or symbolize. For example, David J. Skal (2001) reads Dawn of the Dead (1978) as a "razor-edged social satire: [it] peopled a shopping mall with flesh-eating zombies, an indelible image of consumerism gone mad" (p. 309). Night of the Living Dead has been interpreted as an imaginative transfiguration of cold war anxiety (Pulliam, 2007). Stephen King (2010) sees the 2004 remake of Dawn of the Dead as a trigger of post-9/11 terrorism anxiety. There is some truth to this widespread constructivist approach, but it is not sufficient to explain why the zombie became a popular horror monster. The constructivist perspective is too narrow in its exclusion of biology and evolved cognition. In the case of zombies, these horror monsters do gain much of their power and salience as metaphors for sociocultural anxieties, but this power works in tandem with (and secondarily to) the literal, predatory, and disease-salient presence of zombies (Clasen, 2010a). The zombie was gradually introduced into pop culture during the 20th century and rose swiftly in popularity and visibility following the commercial success of Romero's groundbreaking film (Pulliam, 2007). It could never have achieved this level of cultural success if it had not connected squarely with adaptive dispositions to fear lethal attack and infectious agents.

\section{The Vampire}

The vampire is an ancient figure found in cultures throughout the world (Carter, 2007). It is enjoying an immense boom in popular culture today (see Figure 1). A vampire is a reanimated

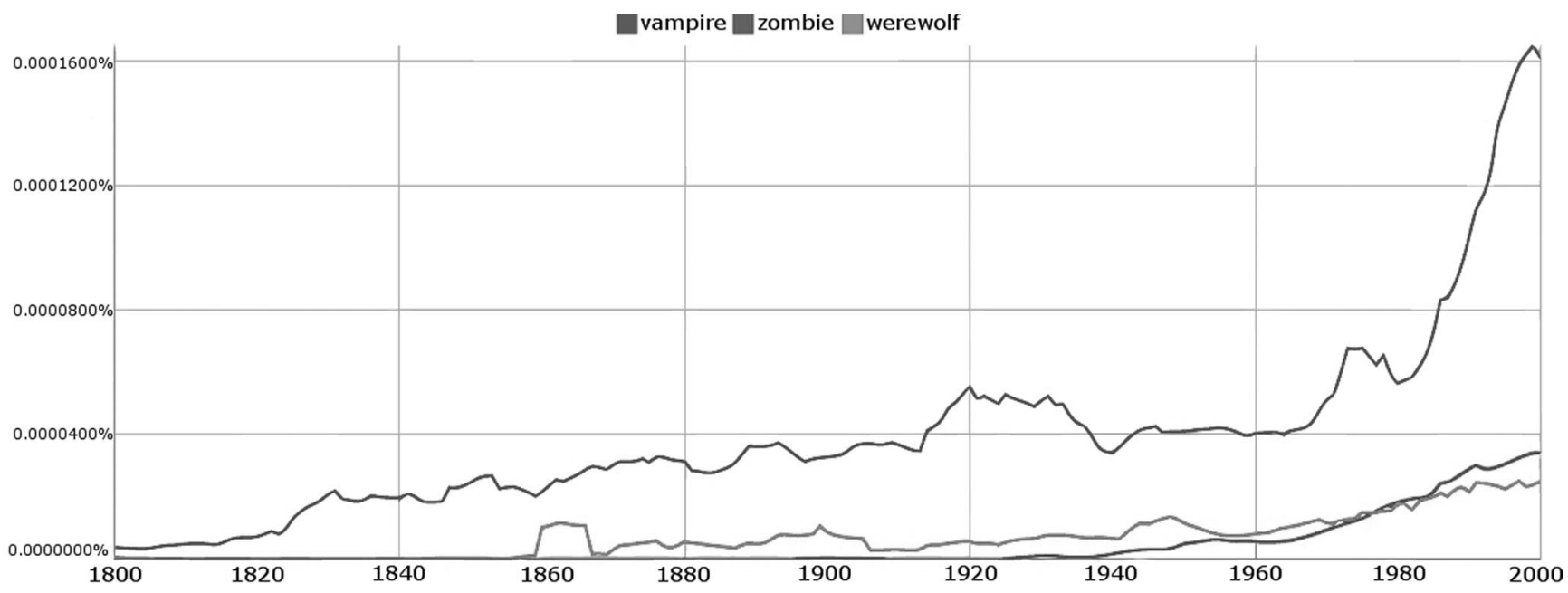

Figure 1. Ngram (Michel et al., 2010). The corpus "English" (containing digitized versions of millions of English-language books) has been searched for occurrences of the terms vampire, zombie, and werewolf to give a rough estimate of the relative popularity of these monsters. At the millennium, the vampire leads vastly, with the zombie a distant second and the werewolf an honorable third. 
corpse whose sole sustenance is the blood of living humans. The vampire has changed and multiplied enormously over the past 300 years, so that today's teen idol vampires from such stories as L. J. Smith's The Vampire Diaries series and Stephenie Meyer's Twilight saga are barely recognizable as descendants of the nocturnal revenants that preyed on rural Eastern European populations in the 18th century (Vanderbeke, 2010). Metaphorically speaking, we have a vampire genotype that is expressed as different phenotypes in different ecologies and modified by cultural selection over time.

Different vampire phenotypes require different explanations. Drawing on archeology, forensic pathology, folklore, and history, Paul Barber (1988) convincingly argues that vampires in the early 18 th century were really a product of a prescientific misunderstanding of biochemical processes. Because nobody had come up with a germ theory of disease, disease was understood in terms of agency, often intentional intervention by supernatural agents, not in terms of invisible microorganisms. (Similarly, the werewolf may have served as an explanation for pathological outbreaks of homicidal violence in the dark ages before professional psychiatry and the fourth edition of the Diagnostic and Statistical Manual of Mental Disorders.) Some modern authors have moved the vampire figure from the uncanny world of demonic forces and supernatural causation to a naturalistic universe of communicable disease, for example, Richard Matheson in his 1954 novel I Am Legend (Clasen, 2010b), thus mirroring the cumulative success of natural science as an explanatory system; Bram Stoker's Van Helsing studies forgotten books of the occult; Matheson's Robert Neville looks at vampire cells in his microscope. The kind of hypersexualized vampires that have recently become popular arguably reflect human female mating strategies, rather than evolutionarily recurrent threats embodied in predatory monsters: These slightly dangerous, highly attractive, and pathologically devoted male vampires seem to condense "cads" and "dads" into one (see Johnson, 2011, on Twilight). Such stories are predominantly about mate choice rather than escaping a dangerous predator. Mate preferences rest on a universal, biological substrate, but they are modulated by cultural norms. It is obviously important to understand the kind of culture that gives rise to for example Stephenie Meyer's odes to unbridled materialism, impossibly attractive people, and idealized romantic love, which could not have arisen in the culture of Eastern Europe in the 18th century. They are at home in contemporary America.

Vampires can be powerful, potent metaphors, but first and foremost they are salient, counterintuitive, usually dangerous monsters, and their ubiquity in popular culture reflects our species' preoccupation with dangerous agents in the environment.

\section{The Ghost}

The ghost is, basically, a disembodied mind, a counterintuitive agent that commands attention and historically has been useful for explaining odd events (missing objects, the impregnation of Mary in the absence of mortal male gametes, the sound you hear from the kitchen just before you fall asleep). Changing theological attitudes and scientific accomplishments alter the significance of ghosts (Finucane, 1984). Nonetheless, all ghosts spring from the same cognitive tendencies: overattributing agency to inexplicable events and an intuitive dualism, that is, our innate tendency to view humans as consisting of material as well as spiritual selves ("souls"; Bloom, 2004; Boyer, 2001). Supposing that a person's immaterial spirit persists after the body dies requires no great leap of faith.

To understand a specific ghost story, we need to understand both the mental machinery that produces and entertains ghosts and the cultural context in which the ghost floats around. For example, the way that Henry James describes his ghosts in The Turn of the Screw (1898) is heavily influenced by late-Victorian "psychical" discourse about spirits and hauntings and also by contemporary "spectral" technologies such as photography and x-rays (Grove, 1997). James's ghosts threaten with an unspecified moral debasement that must be understood in relation to Victorian mores and norms of propriety. Nonetheless, James's story can still send a shiver down the spine of a reader far removed from fin de siècle Britain.

In the 1979 horror film The Amityville Horror, the evil spirits are significant in terms of financial, rather than spiritual, ruin. A family moves into a haunted house, which is soon being ripped apart by ghosts. The film came out in the wake of the economic recession of the mid-1970s, and as Stephen King (1983) recollects, "I found myself wondering not if [the protagonists] would get out alive but if they had adequate homeowner's insurance" (p. 143). King's observation rings true. The film probably tapped into widespread economic anxiety and used ghosts as a metaphor for the sort of apparently impenetrable, malicious, and ultimately unreasonable forces that can ruin you financially. Nonetheless, the ghosts are more than metaphors: They are plain creepy in their literal reality-violating, vengeful aspect. Moreover, the fear of financial ruin is obviously dependent on local socioeconomic parameters and was particularly salient in this age of recession, but it rests on a biological substrate. Insofar as material resources are a proximate means to achieve the ultimate goal of reproductive success (Cronk, 1991), it should come as no surprise that people generally attempt to avoid going broke. Moreover, although the culturally contingent subtext of The Amityville Horror gave it an edge to contemporary viewers, it can still frighten audiences that are not particularly concerned with impending bankruptcy. That is because malicious, dangerous ghosts are frightening crossculturally, to Stone Age cave dwellers and the citizens of modern nation-states alike.

Monsters vary, but not endlessly and not arbitrarily. They are variations on evolutionarily constrained themes. Different ecologies provide different configurations of imaginative spaces in which monsters grow. These ecologies, whether broadly cultural or psychologically individual, are in turn circumscribed by human nature. This is something that the successful horror writer, director, or programmer intuitively knows: He or she is like a locksmith, forging a monstrous key that fits in the cognitive lock of an organism that is shaped by universal nature and further calibrated by local culture.

\section{Functions of Fictional Fear}

Horror fiction capitalizes on cognitive and physiological machinery that is a product of natural selection. Some horror fictions rely on powerful fear or even terror responses (and few horror film directors are loath to throw in a startling scare or two), and others are more dependent on low-key anxiety-provoking storylines and monsters. Common to the outright horrifying and the more subtly 
disturbing horror stories is that they evoke strong emotion and have us raptly probing the fictional landscape for danger.

If horror stories by "artificially" activating adaptations for danger management invoke negative emotion in their audiences, why do some people actively seek out such experiences? We know that certain demographic populations are more likely than others to find horror stories attractive, particularly as pertains to horror films. Adolescent males top the list (Hoffner \& Levine, 2005; Weaver \& Tamborini, 1996). Many horror films feature disgusting contents (decaying monsters, bodily mutilations, and so on). Females have been shown to be higher in disgust sensitivity than males, probably as a defensive function of immunosuppression during parts of the reproductive cycle (Liénard, 2011, pp. 10691070). Women might thus be less likely to enjoy the more disgustdependent horror films, like some slasher films and works in the "gorenography" subgenre. Research has shown that sensationseeking personality traits are correlated with a preference for horror films (reviewed in Hoffner \& Levine, 2005), and adolescent males display the highest tendency to engage in dangerous or quasi-dangerous behavior (Arnett, 1996). Pierre Liénard (2011) notes that males are more likely "to be in intense competition with same-sex conspecifics" and to form coalitions and strong malemale bonds, particularly in adolescence and young adulthood ( $p$. 1071). Perhaps horror films provide a stage for almost ritualistic male-male challenges: Like rites of passage, horror films may serve as a kind of intragroup challenge and also reinforce group bonds. The affirmation of such bonds may be what the ordeal of sitting through a horror film produces: not just "I made it," but "We made it-together."

One study found that respondents reported enjoying a horror film more if an opposite sex coviewer reacts in a "genderappropriate" way (i.e., fearlessness or mastery of fear for boys, fearfulness or distress for girls). In this study, subjects were exposed to a clip from Friday the 13th Part 3 (1982). Male respondents in the company of visibly distressed females claimed to enjoy the clip about twice as much as those in the company of fearless female peers (Zillmann \& Weaver, 1996). Likewise, girls enjoyed watching a film in the company of a scared boy considerably less than in the company of a fearless one. Moreover, respondents rated coviewers as more attractive when their coviewers reacted gender-appropriately to the clip. Perhaps a misattribution of arousal partly accounts for this finding (cf. Dutton \& Aron, 1974); the arousal elicited by the film clip is misinterpreted as arousal caused by the coviewer, which then leads to an inflated attractiveness rating as a result of rationalization and is exacerbated when the coviewer reacts in the desired gender-appropriate way: "Something has gotten me hot under the collar. Maybe it's the person screaming/coping admirably next to me. That person must be very desirable." This phenomenon has become known as the snuggle theory of horror: that horror films can provide a setting for amorous adolescents to react in socially sanctioned, genderspecific ways and cuddle up in the semidarkness of the cinema.

We need to go deeper than gender roles and socialization theories to find the appeal of horror. We have already seen how the human danger-management system is an adaptation that requires calibration to local environments. The need for calibration is a solution to the problem that human genes do not "know" exactly which dangers their host will encounter during its life span, although they will have a pretty good idea. A child growing up in
Sub-Saharan Africa faces certain dangers that are different from those faced by an Inuit child and so needs to learn about them. The key, from the viewpoint of natural selection, is to make such learning pleasurable. Hence, finding pleasure in vicarious learning about dangerous agents and situations is adaptive.

Steen and Owens (2001) argue that human chase play specifically is adaptive in that it helps to mature a child's predator detection and evasion skills. Natural selection has made play behavior self-rewarding, simply because play is adaptive: We, and all other mammalian infants in whom it has been looked for, exhibit a remarkable tendency to spontaneously engage in play and exploratory behavior. These apparently nonfunctional behaviors actually develop skills that are likely to become critically important later in life (Špinka, Newberry, \& Bekoff, 2001). If one meets a hungry predator for the first time, it is desirable to have a store of surrogate experience with predator evasion to draw from rather than proceed by trial-and-error. Thus, like pretend play, fiction is a kind of mental simulation (Oatley, 1999) that gives us surrogate experience risk-free and at low cost (Carroll, 1999, 2011; Tooby \& Cosmides, 2001). Scary stories about dangerous monsters illustrate this principle well (Sugiyama, 2006).

The fascination with monsters that many people (especially children) feel is probably the result of an adaptive tendency to pay attention to such dangerous agents and to learn about their behavior vicariously, what H. Clark Barrett called the "Jurassic Park hypothesis" (2005, p. 218). In this view, the modern horror story is a kind of supernormal stimulus, a hypertrophied variation on chase play: It is a technology that enlists all manner of monstrous agents to tap into an adaptive motivational system for learning about danger and to calibrate our responses to danger. As Kim Newman (2011) put it, "the central thesis of horror in film and literature is that the world is a more frightening place than is generally assumed" (p. 5). Consuming horror fiction could thus be adaptive. It has all the benefits of learning about danger and one's own response to danger, but without the risk of actual harm. One reviewer (Wong, 2000), looking back at Jaws (1975), noted how in the wake of this film, a "mundane event like going for a swim at the beach just wasn't the same again ... just like many people stopped taking showers after seeing Psycho." To cease showering is probably not very adaptive, unless one finds alternative means of personal hygiene, whereas showing a greater degree of vigilance while bathing in the sea-even if great white sharks very rarely attack people — could be a sensible strategy.

As Asma (2009) wrote, monsters "probably appear and reappear in our stories and in our artwork because they help us (and helped our ancestors) navigate the dangers of our environment" (pp. 283-284). Asma's functional thesis fits snugly in the biocultural framework outlined here. Pointing out that the monster is a universal figure, he plausibly suggests that "stories about monster threats and heroic conquests provide us with a ritualized, rehearsable simulation of reality, a virtual way to represent the forces of nature, the threats from other animals, and the dangers of human social interaction" (pp. 282-283). Sometimes horror stories can be traumatic (cf. Cantor \& Oliver, 1996), sometimes the pleasure of watching a horror movie is subordinate or even incidental to the pleasure of getting together with friends, and sometimes the negative emotion evoked by a horror story is a nuisance for the reader interested in other qualities offered by the story. Presumably, some readers enjoy Stephen King's descriptions of human interactions 
and mental machinations, but wish that he would turn it down a notch on the scary stuff. At any rate, horror stories are ubiquitous in popular culture because they are effective at what they do. And what they do is provide an imaginative space in which thrilling, uncanny encounters with all manner of monsters can take place. If ancestral environments had not been dangerous, if we were all perfectly fearless, we would have no horror stories today: no bloodsucking vampires, no scary ghosts, no howling werewolves.

\section{Evolution, Cognition, Culture: An Integrated Approach}

There is no good epistemological reason for ignoring evolution and cognition in the study of culture. Horror fiction is a good example: Scholars of horror fiction have everything to gain from adopting a biocultural perspective, one that integrates attention to historical circumstance with knowledge of human evolutionary history and evolved cognitive architecture. Such an integrated approach has the potential of adding analytic richness and boosting explanatory power in the study of horror fiction. It avoids the pitfall of unnecessary monocausal reductionism, both in constructivist and evolutionary approaches: An attempt to explain horror fiction by appealing only to biological hard-wiring is as futile as appealing only to cultural contingency. Only a fully integrated biocultural approach is up to the task of making sense of the monsters that prowl our storyscapes.

\section{References}

Arnett, J. J. (1996). Sensation seeking, aggressiveness, and adolescent reckless behavior. Personality and Individual Differences, 20, 693-702. doi:10.1016/0191-8869(96)00027-X

Asma, S. T. (2009). On monsters: An unnatural history of our worst fears. Oxford, England: Oxford University Press.

Barber, P. (1988). Vampires, burial, and death: Folklore and reality. New Haven, CT: Yale University Press.

Barrett, H. C. (2005). Adaptations to predators and prey. In D. M. Buss (Ed.), Handbook of evolutionary psychology (pp. 200-223). New York, NY: Wiley.

Barrett, J. L. (2004). Why would anyone believe in God? Walnut Creek, CA: Altamira Press.

Bloom, P. (2004). Descartes' baby: How the science of child development explains what makes us human. New York, NY: Basic Books.

Boyer, P. (2001). Religion explained: The evolutionary origins of religious thought. New York, NY: Basic Books.

Boyer, P., \& Bergstrom, B. (2011). Threat-detection in child development: An evolutionary perspective. Neuroscience \& Biobehavioral Reviews, 35, 1034-1041. doi:10.1016/j.neubiorev.2010.08.010

Boyer, P., \& Liénard, P. (2006). Why ritualized behavior? Precaution systems and action parsing in development, pathological and cultural rituals. Behavioral and Brain Sciences, 29, 595-613. doi:10.1017/ S0140525X06009332

Cantor, J., \& Oliver, M. B. (1996). Developmental differences in responses to horror. In J. B. Weaver \& R. Tamborini (Eds.), Horror films: Research on audience preference and reactions (pp. 63-80). Hillsdale, NJ: Erlbaum.

Carroll, J. (1999). The deep structure of literary representations. Evolution and Human Behavior, 20, 159-173. doi:10.1016/S1090-5138(99) 00004-5

Carroll, J. (2011). Reading human nature: Literary Darwinism in theory and practice. New York, NY: SUNY University Press.
Carter, M. L. (2007). The vampire. In S. T. Joshi (Ed.), Icons of horror and the supernatural (pp. 619-652). Westport, CT: Greenwood Press.

Clasen, M. (2010a). The anatomy of the zombie: A bio-psychological look at the undead other. Otherness: Essays and Studies, 1, 1-23.

Clasen, M. (2010b). Vampire apocalypse: A biocultural critique of Richard Matheson's I Am Legend. Philosophy and Literature, 34, 313-328. doi:10.1353/phl.2010.0005

Cronk, L. (1991). Wealth, status, and reproductive success among the Mukogodo of Kenya. American Anthropologist, 93, 345-360. doi: 10.1525/aa.1991.93.2.02a00040

Dutton, D. G., \& Aron, A. P. (1974). Some evidence for heightened sexual attraction under conditions of high anxiety. Journal of Personality and Social Psychology, 30, 510-517. doi:10.1037/h0037031

Eilam, D., Izhar, R., \& Mort, J. (2011). Threat detection: Behavioral practices in animals and humans. Neuroscience \& Biobehavioral Reviews, 35, 999-1006. doi:10.1016/j.neubiorev.2010.08.002

Feinstein, J., Adolphs, R., Damasio, A., \& Tranel, D. (2011a). The human amygdala and the induction and experience of fear. Current Biology, 21, 34-38. doi:10.1016/j.cub.2010.11.042

Feinstein, J., Adolphs, R., Damasio, A., \& Tranel, D. (2011b). The human amygdala and the induction and experience of fear [Supplemental information]. Current Biology, 21, 1-11. Retrieved from http:// download.cell.com/current-biology/mmcs/journals/0960-9822/ PIIS0960982210015083.mmc1.pdf. doi:10.1016/j.cub.2010.11.042

Finucane, R. C. (1984). Appearances of the dead: A cultural history of ghosts. Buffalo, NY: Prometheus Books.

Gilmore, D. D. (2003). Monsters: Evil beings, mythical beasts, and all manner of imaginary terrors. Philadelphia, PA: University of Pennsylvania Press.

Grodal, T. K. (2009). Embodied visions: Evolution, emotion, culture, and film. Oxford, England: Oxford University Press.

Gross, J., \& Levenson, R. (1995). Emotion elicitation using films. Cognition \& Emotion, 9, 87-108. doi:10.1080/02699939508408966

Grove, A. W. (1997). Röntgen's ghosts: Photography, X-rays, and the Victorian imagination. Literature and Medicine, 16, 141-173. doi: 10.1353/lm.1997.0016

Hart, D., \& Sussman, R. W. (2008). Man the hunted: Primates, predators, and human evolution (Expanded ed.). Boulder, CO: Westview Press.

Hill, K., \& Furtado, A. M. (1996). Aché life history: The ecology and demography of a foraging people. New York, NY: de Gruyter.

Hoffner, C. A., \& Levine, K. J. (2005). Enjoyment of mediated fright and violence: A meta-analysis. Media Psychology, 7, 207-237. doi:10.1207/ S1532785XMEP0702_5

Johnson, J. A. (2011). Vampires are real: An evolutionary view of the Twilight saga. The Evolutionary Review: Art, Science, Culture, 2, 113 118.

Kendrick, W. (1992). The thrill offear. New York, NY: Grove Weidenfeld. King, S. (1983). Danse macabre. New York, NY: Berkley Books.

King, S. (2010). What's scary: A forenote to the 2010 edition. In S. King, Danse macabre (pp. 11-37). New York, NY: Pocket Books.

LeDoux, J. (1996). The emotional brain: The mysterious underpinnings of emotional life. New York, NY: Simon \& Schuster.

Liénard, P. (2011). Life stages and risk-avoidance: Status- and contextsensitivity in precaution systems. Neuroscience \& Biobehavioral Reviews, 35, 1067-1074. doi:10.1016/j.neubiorev.2010.09.007

Marks, I. M., \& Nesse, R. M. (1994). Fear and fitness: An evolutionary analysis of anxiety disorders. Ethology and Sociobiology, 15, 247-261. doi:10.1016/0162-3095(94)90002-7

McCarty, M., \& McLaughlin, M. (2006). John Carpenter looks back at Halloween on its 25th anniversary. Science Fiction Weekly, 9. Retrieved from http://www.scifi.com/sfw/issue339/interview.html

Michel, J.-B., Shen, Y. K., Aiden, A. P., Veres, A., Gray, M. K., Google Books Team, ... Aiden, E. L. (2011, January 14). Quantitative analysis 
of culture using millions of digitized books. Science, 331, 176-182. doi:10.1126/science.1199644

Neuberg, S., Kenrick, D., \& Schaller, M. (2011). Human threat management systems: Self-protection and disease avoidance. Neuroscience \& Biobehavioral Reviews, 35, 1042-1051. doi:10.1016/j.neubiorev .2010.08.011

Newman, K. (2011). Nightmare movies: Horror on screen since the 1960s (Rev. ed.). London, England: Bloomsbury.

Norenzayan, A., Atran, A., Faulkner, J., \& Schaller, M. (2006). Memory and mystery: The cultural selection of minimally counterintuitive narratives. Cognitive Science, 30, 531-553. doi:10.1207/ s15516709cog0000_68

The Numbers. (2011). Top-grossing genres 1995 to 2011. Retrieved from http://www.the-numbers.com/market/Genres/

Oatley, K. (1999). Why fiction may be twice as true as fact: Fiction as cognitive and emotional simulation. Review of General Psychology, 3, 101-107. doi:10.1037/1089-2680.3.2.101

Öhman, A. (2000). Fear and anxiety: Evolutionary, cognitive, and clinical perspectives. In M. Lewis \& J. M. Haviland-Jones (Eds.), Handbook of emotions (2nd ed., pp. 573-593). New York, NY: Guilford Press.

Öhman, A., Flykt, A., \& Esteves, F. (2001). Emotion drives attention: Detecting the snake in the grass. Journal of Experimental Psychology: General, 130, 466-478. doi:10.1037/0096-3445.130.3.466

Öhman, A., \& Mineka, S. (2001). Fears, phobias, and preparedness: Toward an evolved module of fear and fear learning. Psychological Review, 108, 483-522. doi:10.1037/0033-295X.108.3.483

Paranormal Activity. (2011). Box office data, movie news, cast information. Retrieved from http://www.the-numbers.com/movies/2009/ PNACT.php

Pulliam, J. (2007). The zombie. In S. T. Joshi (Ed.), Icons of horror and the supernatural (pp. 723-753). Westport, CT: Greenwood Press.

Rose, C. (2000). Giants, monsters, and dragons: An encyclopedia of folklore, legend, and myth. New York, NY: Norton.

Rottenberg, J., Ray, R., \& Gross, J. (2007). Emotion elicitation using films. In J. A. Coan \& J. J. B. Allen (Eds.), The handbook of emotion elicitation and assessment (pp. 9-28). New York, NY: Oxford University Press.

Shepard, P. (1996). The others: How animals made us human. Washington, DC: Island Press.
Skal, D. J. (2001). The monster show: A cultural history of horror (Rev. ed.). New York, NY: Faber \& Faber.

Špinka, M., Newberry, R. C., \& Bekoff, M. (2001). Mammalian play: Training for the unexpected. Quarterly Review of Biology, 76, 141-168. Retrieved from http://www.jstor.org/pss/2664002. doi:10.1086/393866

Steen, F. F., \& Owen, S. A. (2001). Evolution's pedagogy: An adaptationist model of pretense and entertainment. Journal of Cognition and Culture, 1, 289-321. doi:10.1163/156853701753678305

Sugiyama, M. S. (2006). Lions and tigers and bears: Predators as a folklore universal. In H. Friedrich, F. Jannidis, U. Klein, K. Mellmann, S. Metzger, \& M. Willems (Eds.), Anthropology and social history: Heuristics in the study of literature (pp. 319-331). Paderborn, Germany: Mentis.

Tooby, J., \& Cosmides, L. (2000). Evolutionary psychology and the emotions. In N. Lewis \& J. M. Haviland-Jones (Eds.), Handbook of emotions (2nd ed., pp. 91-115). New York, NY: Guilford Press.

Tooby, J., \& Cosmides, L. (2001). Does beauty build adapted minds? Toward an evolutionary theory of aesthetics, fiction and the arts. SubStance, 30, 6-27. doi:10.1353/sub.2001.0017

Vanderbeke, D. (2010). The vampire strikes back: On the history of a nightwalker. Fastitocalon, 1, 3-19.

Wade, N. (2007). Before the dawn: Recovering the lost history of our ancestors. London, England: Duckworth.

Weaver, J. B., \& Tamborini, J. (Eds.). (1996). Horror films: Current research on audience preferences and reactions. Hillsdale, NJ: Erlbaum.

Wong, J. (2000). Review of film Jaws (1975). Retrieved from http:// www.moviemutterings.com/reviews/j/jaws.htm

Woody, E., \& Szechtman, H. (2011). Adaptation to potential threat: The evolution, neurobiology, and psychopathology of the security motivation system. Neuroscience \& Biobehavioral Reviews, 35, 1019-1033. doi: 10.1016/j.neubiorev.2010.08.003

Zillmann, D., \& Weaver, J. B. (1996). Gender socialization theory of reactions to horror. In J. B. Weaver \& R. Tamborini (Eds.), Horror films: Research on audience preference and reactions (pp. 81-101). Hillsdale, NJ: Erlbaum.

Received February 8, 2012

Revision received February 8, 2012

Accepted February 22, 2012 